\title{
The Current State and Historico-geographical Background of Mt. Chirisan Region Immigrants*
}

Kang Sungho**

\section{Introduction}

After the 1988 Olympic Games in Seoul, Korea experienced rapid changes as a multiracial country due to the steep increase in foreign immigrants. The majority of foreign immigrants in Korea consists of foreign workers, female immigrants for international marriage, and international students from China, Japan, South East Asia, and South West Asia. ${ }^{1}$ The United Nations categorizes a nation as a multiracial country when more than $2 \%$ of the country's population consists of foreigners. As there were $1,780,000$ foreigners in Korea, which made up 3.56\% of the total population in 2014, Korea became a multiracial country. ${ }^{2}$ If this trend continues, approximately $10 \%$ of Korean population is expected to be immigrants in 2030; therefore, social integration problems with the new immigrants are expected to emerge as a main conflicting issue. ${ }^{3}$

* This work was supported by the National Research Foundation of Korea Grant funded by the Korean Government (NRF-2007-361-AM0015).

** Professor, Department of History, Sunchon National University

1 Ko Byŏng-kap, Tamunhwasahoe ŭi Tamunhwajŏngch'aek e taehan Sŏnhaengyeongu (Studies on Multicutural Policy based on Multiculturalism," Chibangjach 'iyŏkk (Studies on Loca lself- government)," 19 (2012): 22.

2 Korea Immigration Service, T'onggyewŏlbo (Monthly Statistics) (Oct. 2014): 11. 
Until now, researches about foreign immigrants have been mainly oriented and focused activities of local governments. Currently, Seoul and Kyŏnggi province are populated by most of the total immigrants in Korea; $24.5 \%$ of the registered foreigners were residing in Seoul, and $32.2 \%$ in Kyŏnggi province by October, 2014. ${ }^{4}$ Simultaneously, the number of immigrants is increasing at a fast rate also in local provinces such as Kangwŏn, Chŏnnam, Chŏnbuk, Kyŏngnam, Kyŏngbuk and so on. It is now important also to address the immigrant issue from a local viewpoint. Immigrant issues in local provinces are often handled by civic units; however, apart from this approach from civic units, research about the characteristics of immigrants according to local situations needs to be encouraged. This is so because immigrants can be categorized differently according to the locality: mountain-side areas, manufactory-centered areas, seaside areas, and urban areas. ${ }^{5}$

There is not much research on immigrants in mountainous regions. Research on immigrants in mountainous regions would help to understand the diverse nature of immigrants in Korea. Mt. Chirisan can be used as a representative mountain in Korea. There is research on immigrants in individual provinces-Chŏnbuk, Chŏnnam, Kyŏngnam- but there has not been a study on Mt. Chirisan as a whole. ${ }^{6}$ As Mt. Chirisan is the largest

3 Chŏng Changyŏp \& Jŏng Sŏngwan, “Hankuk tamunhwag Chŏk Chŏngch'aek ŭi Chŏnghangsŏng Punsŏk: Tonghwajuŭi wa Tamunhwajuŭi(Characteristics of Multicultural Family Policy in Korea: Assimilation or Multiculturalism)," Chibangjŏngbuyŏngu (The Korean Journal of Local Government Studies), 17, no. 4 (Winter 2014): 128.

4 Korea Immigration Service, Tonggyeweolbo (Monthly Statistics) (October 2014): 13.

5 An Mijŏng, "Haehangdosi ŭi Yijuja: Busansi Haenyŏ Community Chongaeyangsang (Migrant of Seaport City: Features of Women Diver's Community in Busan, Korea," Yŏksawagyŏngye (History and Border), 89 (December 2013).

6 Li, Sŭng-hee, "Chŏnamjiyŏk ŭi Tamunhwa Hyŏnsang: Chiyŏkch'ukje wa Tamunhwa Kajok ŭi Sangkwangwangye rŭl Chungsim ŭro (Multicultural Phenomena in South Jolla Province: an Analysis of Interactions between Local Festival and Multicultural Families)," Ch'asedae Inmunsahoeyŏngu(Study on Future 
mountain in Korea, research on immigrants in this region would set a milestone in comprehending the nature of Korean mountain range immigrants.

To understand 'Mt. Chirisan Region' immigrants, we need to define the range of Mt. Chirisan. After defining this "Mt. Chirisan Region," the purpose would be to clarify the current state and historical/geographical background of the Mt. Chirisan area immigrants and its characteristics, and to search for ways to socially integrate these immigrants.

\section{The "Mt. Chirisan area"}

Only recently has the Mt. Chirisan Region area and Chirisan culture started to be used as an academic category. The Mt. Chirisan Region as a category came into use after Sunchon National University founded the Institute of Mt. Chirisan Region Culture in April of 2007, and its research team commenced their research at full-scale in October, 2007.

The Mt. Chirisan Region can be defined differently according to diverse standards: geospatial standards, natural ecological standards, population administrative standards, and such. As low-altitude low-acid mountain range and hills are well-developed in Korea, it is difficult to tell a mountain from a flatland. The opinion that $70 \%$ of the Korean territory consists of mountains has its root upon the Korea Forest Foundation's estimate according to woods and fields, based on the forestry-based definition of mountains. ${ }^{7}$ Defining the geospatial location of Mt. Chirisan Region differs upon standards. ${ }^{8}$ Even in topography, the quantitative specification of a "mountain" ranges from over $200 \mathrm{~m}$ to $600 \mathrm{~m}$ above sea

Humanties and Social Science), vol. 8 (Dec. 2011).

7 T'ak Hanmyŏng, Kim Sŏnghan, Son Il, “Chihyŏnghakjŏk Sanji ŭi Punp'o wa Konggan Chŏk T'ŭksŏng ae taehan Yŏngu (Study on Geographical Distribution and Spatial Characteristics)," Taehanjirihakhoeji (Journal of Korean Geographical Society), 48, no.1 (2013): 2. 
level. From the aspect of natural ecological standards, where preservation and administration is the main focus, $500 \mathrm{~m}-600 \mathrm{~m}$ above sea level is defined as the Mt. Chirisan Region; this complies with the extent of Chirisan National Park. ${ }^{9}$ The area has its reach over three provinces, one city, four Kun, and fifteen of the Eup/Myŏn administrative division; its magnitude is $483.022 \mathrm{~km}^{2}$, making it the biggest mountain-type national park of the 20 national park in Korea.

Figure 1. Overall Map of Mt. Chirisan National Park

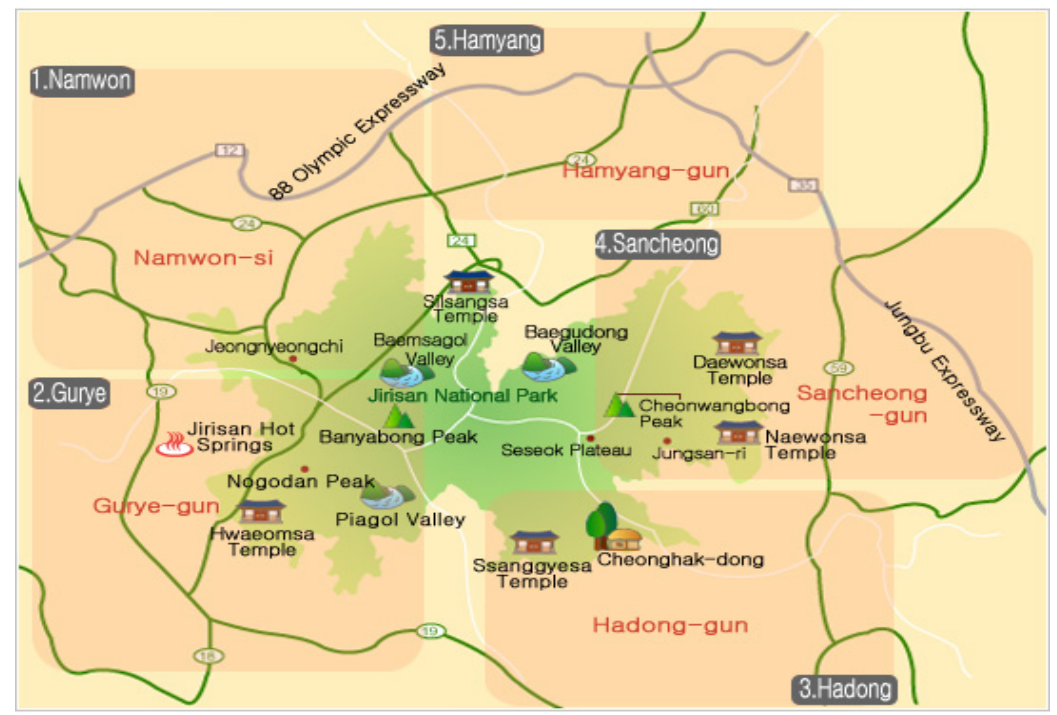

This natural ecological division is a narrow range which disregards the

8 Choe Wŏnsŏk, "Mt. Chirisan kwa Mt. Hallasan ŭi Yŏksajiri chŏk Paegyŏng kwa Hyŏnhwang Pigyo Koch'al( Comparative Research on the Histo-geographical Background of Mt. Chirican and Mt. Hallasan)," Namdo Munhwa Yŏnku (The Journal of Namdo Cultural Studies), 26, (June 2014): 273.

9 Korea National Park Service, Mt. Chirisan Kukrip Kongwŏn Saengmulgwŏn Pojŏnjiyŏk (Biosphere Reserve of Mt. Chirisan National Park ) (2013). 
village activity advanced in $200 \mathrm{~m}$ above sea level, or semi-mountain range. So if we see this semi-mountain range as Mt. Chirisan Region, it becomes easier to comprehend the mountainous, historical, and cultural aspect of Mt. Chirisan Region at the same time. ${ }^{10}$ Villages are widely spread out through Mt. Chirisan between $200 \mathrm{~m}$ to $400 \mathrm{~m}$ above sea level in Mt. Chirisan. ${ }^{11}$ More than half of the total villages are located below $400 \mathrm{~m}$ above sea level; less than half of them are located in the $400 \mathrm{~m}$ $600 \mathrm{~m}$ above sea level range; then there is a sharp decrease in the number of villages above $700 \mathrm{~m}$, ending with very few villages above $800 \mathrm{~m}$. From this, it can be inferred that village activity is lively around $200 \sim 400 \mathrm{~m}$ above sea level. Therefore, Mt. Chirisan Region incorporated with the semi-mountain range can help understand economic and cultural activity, along with its mountainous features. Areas abutting Mt. Chirisan National Park and Mr. Jiri's semi-mountain range includes Chŏnbuk Namwŏn city $\left(111.482 \mathrm{~km}^{2}\right)$, Chŏnnam Kurye-kun (100.809km²), Kyŏngnam Sanchŏngkun $\left(270.731 \mathrm{~km}^{2}\right)$, Hadong-kun $\left(86.255 \mathrm{~km}^{2}\right)$, Hamyang-kun $\left(72.360 \mathrm{~km}^{2}\right)$, $641.637 \mathrm{~km}^{2}$ in total. ${ }^{12}$

Mt. Chirisan Region enlarges when seen in light of administrative aspects and economic activities. Areas included in this definition of Mt. Chirisan are 3 provinces, 7 city/kuns (Namwŏn, Changsu, Koksŏng, Kurye, Hadong, Sanch'ŏng, Hamyang); Chŏnbuk Changsu -kun and Chŏnnam Koksŏng -kun is added relative to 5 city/Kns that borders Mt. Chirisan National Park and Mt. Chirisan semi-mountain range. Also, in this range, flatlands below $200 \mathrm{~m}$ that are situated below the semimountain range are also included. The gross area of this range is

10 Choe Wŏnsŏk, "Comparative Research on the Histo-geographical Background of Mt. Chirican and Mt. Hallasan": 274.

11 Jung Chi-Young, Mt. Chirisan ŭi Nongyŏp kwa Chŏnrakyŏngu (Study on Agriculture and Village in Mt. Chirican), ( Seoul: Research Institute of Korean Studies at Korea University 2006): 357.

12 Chŏng Ch'i-yŏng, Study on Agriculture and Village in Mt. Chirisan : 358. 
Figure 2. Guide Map to Mt. Chirisan National Park

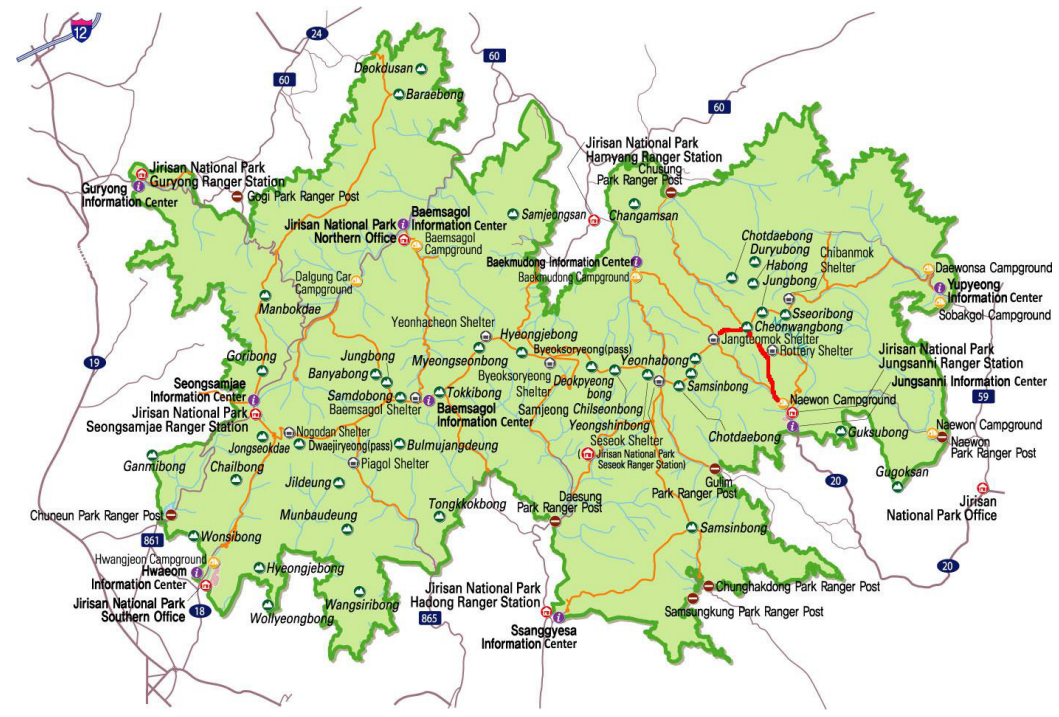

$4,470.9 \mathrm{~km}^{2}$, accounting for $4.5 \%$ of the national territory. The extent of area is easily much more expansive than Mt. Chirisan National Park $\left(483.022 \mathrm{~km}^{2}\right)$, and the Mt. Chirisan semi-mountain range $\left(641.637 \mathrm{~km}^{2}\right)$.

The 7 city/kuns adjacent to Mt. Chirisan have organized the Mt. Chirisan Region Chief Committee and have been making joint cooperative progress for the last 10 years. One of the representative outcomes of this Committee's joint work is the Mt. Chirisan Tourism Development Union, which has made joint progress from 2007 to $2017 .{ }^{13}$ The 7 city/kuns in Mt. Chirisan Region formed Mt. Chirisan Region Chief Committee in 1998, and founded the Mt. Chirisan Tourism Development Union in compliance with the advice from the Ministry of Culture, Sports, and Tourisms (MCST), as the "Mt. Chirisan Region Expansive Tourism Development Plan was confirmed. The Mt. Chirisan Tourism Development Union had been promoting 16 business projects, such as Mt. Chirisan

13 http://www.jirisantour.go.kr (Oct. 1. 2015). 
Region Souvenir development, for the past ten years.

A private organization similar to this Committee is the Mt. Chirisan Region Cultural Director Committee (Chirisankwŏn Munhwawŏnjang Hyŏbŭihoe), consisting of 7 city/kuns (Namwŏn, Changsu, Kurye, Koksŏng, Hadong, Sanchŏng, Hamyang). The Mt. Chirisan Region Culture Director Committee was formed to provide education about Mt. Chirisan's regional culture, separate from the Mt. Chirisan Tourism Development Union. However, due to insufficient manpower and finances to run the Committee, it is relatively inactive. The Director Committee established an agreement with the Institute of Mt. Chirisan Region Culture at Sunchon National University, and is discussing the registration of Mt. Chirisan as a World Complex Heritage in UNESCO or joint management of Mt. Chirisan Traditional Culture Exhibition businesses that are being promoted by the Academy of Korean Studies.

In addressing issues with immigrants in the Mt. Chirisan Region, administrative, economic approaches hold more meaning than natural ecological or geospatial approaches. Since immigration issues in Korea are deeply related to jobs and marriage, such an approach helps to grasp the problem immigrants are facing. Also, if the Mt. Chirisan Region Culture Director Committee, Mt. Chirisan Tourism Development Union, and Mt. Chirisan Region Chief Committee cooperate, it would help in understanding the issues related to immigrants in Mt. Chirisan Region. Therefore, this essay focuses on 3 provinces and 7 city/kuns' immigrants' current present situations, characteristics, and integration problems

\section{Historical/Ggeographical Background of Mt. Chirisan Region Immigrants}

As Mt. Chirisan is the terminal point of Paekdudaegan Mountain and the dividing point for Naknam-Chŏngmaek, it clearly shows the continuous and connective relationship these mountain ranges share. Therefore, this mountain-branch system has its own "stem" and "branch" hierarchy, 
which shows joint connections. The channel network of Mt. Chirisan is depicted as a dendritic pattern, and the radial shape pattern by the standards of east-west branch ridge, largely categorized as Nakdong River as the east basin zone, and Sormjin River as the west. As the river channel meanders greatly and its water quantity big, it is fit for agricultural use and for villages' formation. ${ }^{14}$

For these reasons, the utilization of soil was actively processed from the ancient periods, easily recognizable from the remnants of the Ancient Three Kingdoms and Kaya, and various temples. According to the Samguksagi 三國史記(the Chronicle of the Ancient Three Kingdom, 1145), the cultivation of crops began in the $9^{\text {th }}$ century, and large-scale cultivation by temples located in Mt. Chirisan centered on the south-sloping valley and banks of the mountain during the Unified Silla 統一新羅(668936) and Koryŏ 高麗 (918 1392) periods. Reclamation and irrigation techniques contributed to the expansion of rice field areas, and the population and villages near Mt. Chirisan greatly increased in the late Chosŏn dynasty. ${ }^{15}$

There are a lot of historical georaphical records about soil and agriculture (rice field and dry-field farming) on the Mt. Chirisan areas in historical documents and Chiriji. ${ }^{16}$ In Yuduryusangi 遊頭流山記 (Pleasant Ac-

14 Choe Wŏnsŏk, "Comparative Research on the Histo-geographical Background of Mt. Chirisan and Mt. Hallasan": 280 1.

15 Choe Wŏnsŏk, "Comparative Research on the Histo-geographical Background of Mt. Chirican and Mt. Hallasan": 282

16 There are a full-scale recording of knowledge about mountains from various perspectives in Korea: Chiriji (地理志, geographical accounts), Yusangi (遊山記, accounts of a mountain tour), Paekkwasajŏn (百科全書, encyclopedia), Sanbo (山譜, mountain genealogy), Chido (地圖, map), and P'ungsurok (風水錄, p'ungsu accounts). The Chiriji volumes of Samguksagi (三國史記, the Chronicle of the Ancient Three Kingdom, 1145) and the Koryǒsa (高麗史, History of Goryeosa, 1454) were compiled and volumes of various Chiriji were published during Joseon dynasty. (Choe Wŏnsŏk, "Korean Mountain Studies: Tradition and Knowledge," Journal of Mountains and Humanities, vol. 1 (September 2015): 95 97) 
counts of Mt. Chirisan Tour) Park Jangwon(1612 1671) said that the soil was proper for rice field farming. We can find descriptions about hwachŏn (slash-and -burn filed) in higher altitudes and rice field farming on hillsides or flatlands in Duryusangi 頭流山記 (Accounts of Mt. Chirisan Tour) of Chŏng Sŏkgu(1772 1883)) $)^{17}$

The reclamation of hillside lands in the Mt. Chirisan Region and the transformation of the reclaimed lands changed from the land-rotation type to labor-intensive rice paddies. ${ }^{18}$ The earlies type of land-use in the Mt. Chirisan Region was a primitive slash-and burn, which has been locally known as hwachŏns opened by those who went into Mt. Chirisan area around the late $17^{\text {th }}$ century. The early frontiersmen were mostly run-way farmers who broke away from the burdensome civilian and military duties imposed by the provincial and central governments.

Rice field farming and irrigation techniques were a turning point in Mt. Chirisan Region agriculture. The productive mountainous environment with less drought and flooding was helpful for the successful establishment of rice fields in this area. Sustainable terraced-fields were formed because of steep hillsides, which required tremendous efforts in engineering skills, folk wisdom and communal cooperation. However, the crop character with high productivity led to the spread of rice fields.

After the Japanese invasion of Korea (1592 98) and the Manchu invasion of Korea (1627, 1636 37), drifters settled in valleys and small basins of Mt. Chirisan, and the distribution of residences expanded into the middle mountainous area. In this situation, the agricultural area near Mt. Chirisan greatly increased. According to Sejongsillok 世宗實錄 (the Chronicle of King Sejong, 1454) and Yǒjidosŏ 輿地圖書 (Book of national land descriptions, 1757 65), the agricultural area near Mt. Chirisan in popula-

17 Choe Wŏnsŏk, "Comparative Research on the Histo-geographical Background of Mt. Chirican and Mt. Hallasan: 26, 283.

18 Chŏng Ch'i-Young, "Chiriansji ŭi Nonggyŏnji Gaegan(The Reclamation Process in Mt. Chirican Region), ” Munhwayŏksajiri (Cultural Histo-geography), 12, no.1 (June 2000). 
tion in the mid- $15^{\text {th }}$ century was 32,514 kyŏl and 36,662 kyŏl by the mid$18^{\text {th }}$ century. ${ }^{19}$ While the total agricultural area increased by $12.7 \%$, the rice field area increased by about 35\%. Because out of 32,514 kyŏl agricultural areas rice fields are about 16,257 kyŏl, making up about half according to the Sejongsillok; out of 36,662 kyŏl agricultural area, rice fields were 22,068 kyŏl, making up $60.1 \%$ according to the Yŏjidosŏ. Rice fields increased by $35.7 \%$ from about 16,257 kyŏl to 22,068 kyŏl during the same period. ${ }^{20}$ From this, it can be inferred that the expansion of rice field farming near Mt. Chirisan was important.

Table 1. Agricultural Area Near Mt. Chirisan in Late Chosŏn Dynasty. ${ }^{21}$

\begin{tabular}{l|c|c|c|c|c|c}
\hline \multirow{2}{*}{ Division } & \multicolumn{2}{|c|}{ Sejongsillok(1454) } & \multicolumn{2}{c|}{ Yŏjidosŏ (1757 1765) } & $\begin{array}{c}\text { Increase } \\
\text { (Numbers) }\end{array}$ \\
\cline { 2 - 7 } & $\begin{array}{c}\text { Number of } \\
\text { Kyŏl }\end{array}$ & $\begin{array}{c}\text { Rice field vs } \\
\text { Dry-fiel }\end{array}$ & $\begin{array}{c}\text { Number } \\
\text { of Kyŏl }\end{array}$ & $\begin{array}{c}\text { Rice } \\
\text { field }\end{array}$ & $\begin{array}{c}\text { Dry- } \\
\text { field }\end{array}$ & $\begin{array}{c}\text { Number } \\
\text { of Gyoel }\end{array}$ \\
\hline Namwŏn & 12,508 & $\begin{array}{c}\text { A little more } \\
\text { Rice field }\end{array}$ & 10,060 & 7,180 & 2,880 & $-2,448$ \\
\hline Kurye & 1,735 & $\begin{array}{c}\text { A little less } \\
\text { Rice field }\end{array}$ & 1,523 & 1,012 & 511 & -212 \\
\hline Unbong & 1,796 & $\begin{array}{c}\text { A little more } \\
\text { Rice field }\end{array}$ & 1,387 & 1,075 & 312 & -409 \\
\hline Hadong & 1,272 & $\begin{array}{c}\text { Rice field is } \\
\text { about 2/3 of } \\
\text { agricultural } \\
\text { area }\end{array}$ & 4,013 & 2,300 & 1,713 & 2,741 \\
\hline Chinju & 12,730 & $\begin{array}{c}\text { A little less } \\
\text { Rice field }\end{array}$ & 15,761 & 8,206 & 7,555 & 3,031 \\
\hline Hamyang & 2,473 & $\begin{array}{c}\text { A little less } \\
\text { Rice field }\end{array}$ & 3,918 & 2,295 & 1,623 & 1,445 \\
\hline Sum & $\mathbf{3 2 , 5 1 4}$ & About 16,257 & $\mathbf{3 6 , 6 6 2}$ & $\mathbf{2 2 , 0 6 8}$ & $\mathbf{1 4 , 5 9 4}$ & $\mathbf{4 , 1 4 8}$ \\
\hline
\end{tabular}

191 kyŏl was $1,859.7 \mathrm{~m}^{2}$ in 1444 , was $1,859.7 \mathrm{~m}^{2}$ in 1634 , and was $10,000 \mathrm{~m}^{2}(1 \mathrm{ha})$ in 1902.

20 Choe Wŏnsŏk, "Comparative Research on the Histo-geographical Background of Mt. Chirican and Mt. Hallasan": 284.

21 Choe Wŏnsŏk, "Comparative Research on the Histo-geographical Background of Mt. Chirican and Mt. Hallasan: 291. 
As a result, today the agricultural area including rice fields has continuously expanded all around the Mt. Chirisan Region: Kurye-kun Sandong-myŏn, Yongbang-myŏn, Gwangui-myŏn, Masan-myŏn, Toji-myŏn for the south-western part; Namwŏn-si Unbong-ŭp, Inwŏl-myŏn for the northern part; Hadong-kun, Akyang-myŏn and such for the southern part.

The population in Mt. Chirisan Region began to increase dramatically with the advance in agricultural technology that came about in the late Chosŏn period. The population near Mt. Chirisan (nowadays Namwŏn, Kurye, Unbong, Hadong, Chinju, Hamyang) in the Sejongsillok was 16,718, and 152,078 in the Yojidosŏ, which is about 9 times the previous population. $^{22}$ This sudden increase seems to have its roots in the political situation where the Japanese invasion of Korea and the Manchu War of 1636 created many drifting people and the social economic situation of agricultural expansion. From this, it can be inferred that the Mt. Chirisan Region was historically a fit place for people to live.

Table 2. Survey of Houses/Population Near to Mt. Chirisan in Late Chosŏn Dynasty ${ }^{23}$

\begin{tabular}{l|c|c|c|c|c|c}
\hline \multirow{2}{*}{ Division } & \multicolumn{2}{|c|}{ Sejongsillok (1454) } & \multicolumn{2}{c|}{ Yŏjidosŏ(1757 1765) } & \multicolumn{2}{c}{ Increase (Numbers) } \\
\cline { 2 - 7 } & House & Population & House & Population & House & Population \\
\hline Namwŏn & 1,300 & 4,912 & 10,782 & 36,306 & 9,482 & 31,394 \\
\hline Kurye & 137 & 677 & 1,869 & 6,922 & 1,732 & 6,245 \\
\hline Unbong & 139 & 551 & 2,024 & 4,823 & 1,885 & 4,272 \\
\hline Hadong & 346 & 1,108 & 3,832 & 17,289 & 3,486 & 16,181 \\
\hline Chinju & 2,220 & 7,522 & 13.966 & 65,098 & 11,746 & 57,576 \\
\hline Hamyang & 428 & 1,948 & 4,763 & 21,640 & 4,335 & 19,692 \\
\hline Sum & 4,570 & 16,718 & 37,236 & 152,078 & 32,666 & 135,360 \\
\hline
\end{tabular}

The residents of the rural villages around Mt. Chirisan were mainly

22 Choe Wŏnsŏk, "Comparative Research on the Histo-geographical Background of Mt. Chirican and Mt. Hallasan": 284.

23 Choe Wŏnsŏk, "Comparative Research on the Histo-geographical Background of Mt. Chirican and Mt. Hallasan": 291. 
farmers. Mountain villages and its population, which had developed since the late Chosŏn dynasty, began to decline because of modernization and an increase in the aging population. ${ }^{24}$ New immigrants from East Asia and Southeast Asia have filled the population vacuum.

\section{The Current State of Mt. Chirisan Region Immigrants}

Current Total Numbers of Immigrants in Korea

The population of foreigners in Korea has increased by 2.4 times from 750,000 to $1,780,000$ in the last decade. Such a rapid increase is based on active population movement locally and nationally due to globalization

Figure 3. Estimate Increase in Korea-residing foreigners 2004-2014 ${ }^{25}$

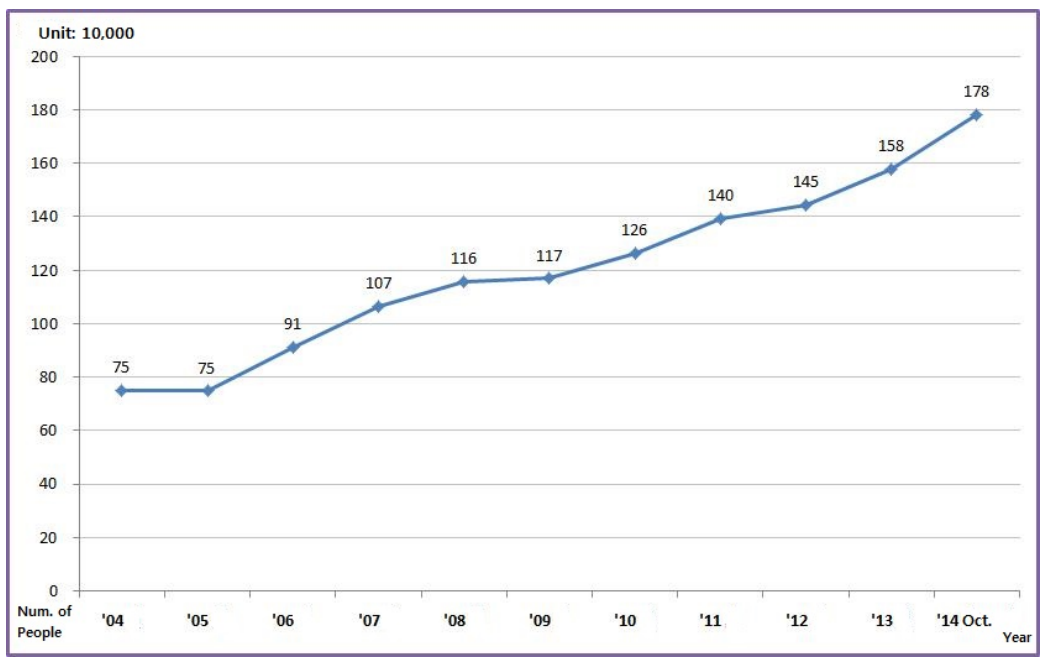

24 Choe Wŏnsŏk, "Comparative Research on the Histo-geographical Background of Mt. Chirican and Mt. Hallasan": 292.

25 Korea Immigration Service, Oct. 2014. 
that is being progressed throughout the globe. Also, the reason for the dramatic influx into Korea is that there was an increase in the need of workers after the rapid industrialization of Korea in the 1960s, and the foreign perception on Korea has increased with the rise in the Korean economy.

This can also be found in the fact that $52 \%$ of the residing foreigners are aged between 20 30 years old. According to a survey on foreigners staying in Korea that had been carried out in October, 2014, people in their twenties amounted to 492,630 , making up $28 \%$ of the total; residents in their thirties amounted to 434,315 , or $24 \%$. Meanwhile, those in their forties were 319,335 (18\%), and their fifties 274,206 (15\%).

Figure 4. Residing Residents Age Distribution. Oct. $312014^{26}$

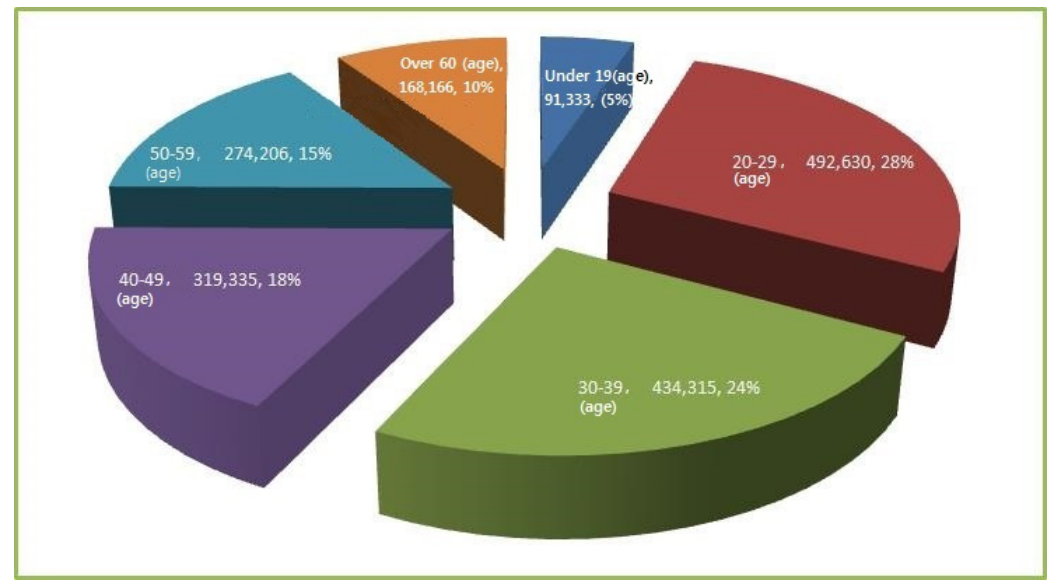

Present Conditions of Registered Mt. Chirisan Foreigners

The estimated Korean gross population for 2014 is 50,423,955, slightly exceeding 50,000,000. However, the official gross population survey is

26 Korea Immigration Service, Oct. 2014. 
conducted every five years and gross population statistics would become clearer when 2015 official survey is revealed. Therefore, though there is some gap between the estimate of 2014 and the actual statistic of 2010, I will examine Mt. Chirisan Region population based on official statistics of 2010. The gross population of Korea in 2010 was 47,990,761; Chŏnbuk, Chŏnnam, and Kyŏngnam had 6,615,364 peoples. 7 Mt. Chirisan-region city/kun lying across these 3 provinces had 220,164 people, $3.32 \%$ of the total population of 3 provinces.

Table 3. Korean Citizens in Mt. Chirisan in $2010^{27}$

\begin{tabular}{l|r|r|r}
\hline Province Division & \multicolumn{1}{c|}{ Sum } & \multicolumn{1}{c}{ Male } & \multicolumn{1}{c}{ Female } \\
\hline Korea & $47,990,761$ & $23,840,896$ & $24,149,865$ \\
\hline Chŏnbuk & $1,766,044$ & 867,630 & 898,414 \\
\hline Namwŏn-si & 78,425 & 37,473 & 40,952 \\
\hline Changsu-kun & 19,293 & 9,170 & 10,123 \\
\hline Chŏnnam & $1,728,749$ & 845,952 & 882,797 \\
\hline Koksŏng-kun & 26,975 & 12,401 & 14,574 \\
\hline Kurye-kun & 22,291 & 10,398 & 11,893 \\
\hline Kyŏngnam & $3,119,571$ & $1,562,686$ & $1,556,885$ \\
\hline Sanchŏng-kun & 31,712 & 14,802 & 16,910 \\
\hline Hadong-kun & 41,468 & 19,568 & 22,100 \\
\hline Hamyang-kun & 37,729 & 17,608 & 20,121 \\
\hline
\end{tabular}

The number of foreigners registered in the Mt. Chirisan Region was 3,334 out of the total 127,943 foreigners in 3 provinces (Chŏnbuk, Chŏnnam, Kyŏngnam), or $2.6 \%$ of the total foreigners in the area. Therefore, the percentage foreigners make up in the Mt. Chirisan Region in the 3 provinces is smaller than that of the percentage Mt. Chirisan residents make up in the 3 provinces, $3.32 \%$. It is expected that, as the Mt. Chirisan

27 Korean Statistical Information Service, 2015 
Region's social economic conditions are no better than those of the urban areas, the population of foreigners should be low. Also, out of the 127,943 foreigners in the 3 provinces, the number of males is 82,818 , making them $64.7 \%$ and female 45,125 , or $35.3 \%$; on the other hand, out of the foreigners in Mt. Chirisan Region, female is 1,945 (58.3\%), and male is $1389(41.7 \%)$, showing a reversed male-female ratio.

Table 4. Current Status of Registered Foreigners in Mt. Chirisan (Sept. 30 2014) ${ }^{28}$

\begin{tabular}{l|r|r|r}
\hline \multicolumn{1}{c|}{ Area Division } & \multicolumn{1}{c|}{ Sum } & \multicolumn{1}{c}{ Male } & \multicolumn{1}{c}{ Female } \\
\hline Korea & $1,078,340$ & 617,378 & 460,962 \\
\hline Chŏnbuk & 25,228 & 13,206 & 12,022 \\
\hline Namwŏn-si & 879 & 356 & 523 \\
\hline Changsu-kun & 369 & 165 & 204 \\
\hline Chŏnnam & 27,285 & 15,528 & 11,757 \\
\hline Koksŏng-kun & 348 & 148 & 200 \\
\hline Kurye-kun & 219 & 61 & 158 \\
\hline Kyŏngnam & 75,430 & 54,084 & 21,346 \\
\hline Sanch'ŏng-kun & 492 & 216 & 276 \\
\hline Hadong-kun & 532 & 217 & 315 \\
\hline Hamyang-kun & 495 & 226 & 269 \\
\hline
\end{tabular}

The reason females from North-East Asia and South-East Asia (such as Vietnamese, Chinese) make up the majority is because most came for marriage. This point can be checked in "Table 5 Registered Foreigners Categorized by Nationality." According to Table 5, the total registered foreign residents in the Mt. Chirisan Region are 3,334. Among this population, Vietnamese make up $33.9 \%$ by 1,131 ; Chinese $21.1 \%$ by 704 ; and Cambodian $12.5 \%$ by 417 . It can be seen that foreigners from South-East Asia and North-East Asia hold the majority, adding 158 Philippines, 138 Thai, 81 Myanmar, and 69 Indonesian.

28 Korean Statistical Information Service, 2015 
Table 5. Registered Foreigners Categorized by Nationality (Sept. 30 2014) ${ }^{29}$

\begin{tabular}{l|c|c|c|c|c|c|c|c}
\hline Division & Sum & $\begin{array}{c}\text { Nam- } \\
\text { wŏn-si }\end{array}$ & $\begin{array}{c}\text { Chang- } \\
\text { su-kun }\end{array}$ & $\begin{array}{c}\text { Koksŏn } \\
\text { g-kun }\end{array}$ & $\begin{array}{c}\text { Kurye- } \\
\text { kun }\end{array}$ & $\begin{array}{c}\text { Hadong } \\
\text {-kun }\end{array}$ & $\begin{array}{c}\text { Sanchŏ } \\
\text { ng-kun }\end{array}$ & $\begin{array}{c}\text { Ha- } \\
\text { myang- } \\
\text { kun }\end{array}$ \\
\hline Vietnam & $\mathbf{1 , 1 3 1}$ & 275 & 121 & 117 & 75 & 214 & 160 & 159 \\
\hline $\begin{array}{l}\text { Korean- } \\
\text { Chinese }\end{array}$ & $\mathbf{3 1 3}$ & 122 & 23 & 35 & 13 & 28 & 48 & 44 \\
\hline $\begin{array}{l}\text { Cambo- } \\
\text { dia }\end{array}$ & $\mathbf{4 1 7}$ & 91 & 61 & 28 & 25 & 87 & 86 & 39 \\
\hline Japan & $\mathbf{1 7 2}$ & 53 & 22 & 23 & 25 & 11 & 10 & 18 \\
\hline $\begin{array}{l}\text { Philip- } \\
\text { pine }\end{array}$ & $\mathbf{1 5 8}$ & 60 & 18 & 16 & 170 & 23 & 12 & 22 \\
\hline Nepal & $\mathbf{1 4 4}$ & 27 & 6 & 10 & 2 & 16 & 47 & 56 \\
\hline Thai & $\mathbf{1 3 8}$ & 28 & 17 & 30 & 4 & 16 & 11 & 32 \\
\hline $\begin{array}{l}\text { Sri } \\
\text { Lanka }\end{array}$ & $\mathbf{9 7}$ & 9 & 11 & 4 & 4 & 25 & 26 & 8 \\
\hline $\begin{array}{l}\text { Uzbeki- } \\
\text { stan }\end{array}$ & $\mathbf{8 2}$ & 23 & 16 & 2 & 9 & 4 & 19 & 10 \\
\hline $\begin{array}{l}\text { Myan- } \\
\text { mar }\end{array}$ & $\mathbf{8 1}$ & 10 & 14 & 3 & 0 & 16 & 19 & 19 \\
\hline $\begin{array}{l}\text { Indone- } \\
\text { sia }\end{array}$ & $\mathbf{6 9}$ & 1 & 10 & 21 & 2 & 23 & 2 & 20 \\
\hline \begin{tabular}{l} 
US \\
\hline Mongol
\end{tabular} & $\mathbf{3 9}$ & 10 & 4 & 6 & 6 & 6 & 4 & 3 \\
\hline $\begin{array}{l}\text { Taiwan } \\
\text { Bangla- } \\
\text { desh }\end{array}$ & $\mathbf{2 8}$ & 18 & 0 & 0 & 4 & 4 & 6 & 5 \\
\hline Canada & $\mathbf{1 5}$ & 3 & 1 & 2 & 2 & 2 & 2 & 3 \\
\hline England & $\mathbf{1 3}$ & 4 & 0 & 2 & 1 & 2 & 1 & 3 \\
\hline Pakistan & $\mathbf{7}$ & 3 & 0 & 1 & 0 & 1 & 2 & 0 \\
\hline India & $\mathbf{3}$ & 1 & 1 & 0 & 0 & 0 & 0 & 1 \\
\hline Russia & $\mathbf{1}$ & 0 & 0 & 0 & 0 & 1 & 0 & 0 \\
\hline Others & $\mathbf{0}$ & 0 & 3 & 1 & 0 & 0 & 0 & 0 \\
\hline Sum & $\mathbf{3 , 3 3 4}$ & $\mathbf{8 7 9}$ & $\mathbf{3 6 9}$ & $\mathbf{3 4 8}$ & $\mathbf{2 1 9}$ & $\mathbf{5 3 2}$ & $\mathbf{4 9 2}$ & $\mathbf{4 9 5}$ \\
\hline & & & & & & & 2 \\
\hline
\end{tabular}

29 Korea Immigration Service, Oct. 2014 
Table 6. Foreigners in Chŏnbuk, Chŏnnam, Kyŏngnam/Mt Chirisan ${ }^{30}$

\begin{tabular}{l|c|c|c}
\hline \multicolumn{1}{c|}{ Area Division } & Sum & Male & Female \\
\hline $\begin{array}{l}\text { Foreigners in } \\
\text { Chŏnbuk, Chŏnnam, } \\
\text { Kyŏngnam }\end{array}$ & 127,943 & 82,818 & 45,125 \\
\hline $\begin{array}{l}\text { Foreigners in Mt. Chi- } \\
\text { risan }\end{array}$ & 3,334 & 1389 & 1,945 \\
\hline
\end{tabular}

In Table 7, job-related foreigners make up the majority. In regard to job employment, 1,107 Non-Professional Employee (E-9) and 229 Visiting Employment (H-2) and such make up $40 \%$ or 1,336. Next are 954 Marriage Immigrants (F-6), 230 marriage immigrants who have permanent residency (F-5), adding up to $35.5 \%$ by total of 1,184 . If we add 630 temporary residents, which make up $18.8 \%$ and consists of 541 Visiting Cohabiter (F-1) and 81 Residing-purpose Visitor (F-2), we can understand that immigrants related to marriage make up the majority. ${ }^{31}$

As city scale is small and economic activities are idle in this mountainrange, urban-style foreigners exists at a very small scale, including 77 Conversation(E-2), 25 Art and Entertainment (E-6), 23 Oversea Studying (D-2), 5 Normal Training (D-4), 3 Technology Training (G-3), 1 Trade Management (D-9).

Table 7. Registered Foreigners Categorize by Staying Purposes. (Sept. 30 2014) (2) $^{32}$

\begin{tabular}{l|c|c|c|c|c|c|c|c}
\hline Category & Sum & $\begin{array}{c}\text { Nam- } \\
\text { wŏn-si }\end{array}$ & $\begin{array}{c}\text { Chang- } \\
\text { su-kun }\end{array}$ & $\begin{array}{c}\text { Koksó } \\
\text { ng-kun }\end{array}$ & $\begin{array}{c}\text { Kurye-- } \\
\text { kun }\end{array}$ & $\begin{array}{c}\text { Hadon } \\
\text { g-kun }\end{array}$ & $\begin{array}{c}\text { Sanchŏ } \\
\text { ng-kun }\end{array}$ & $\begin{array}{c}\text { Ha- } \\
\text { myang- } \\
\text { kun }\end{array}$ \\
\hline $\begin{array}{l}\text { Non-Profession } \\
\text { (E-9) }\end{array}$ & $\mathbf{1 , 1 0 7}$ & 210 & 146 & 101 & 27 & 207 & 246 & 170 \\
\hline $\begin{array}{l}\text { Marriage Mi- } \\
\text { grant (F-6) }\end{array}$ & $\mathbf{9 5 4}$ & 276 & 96 & 105 & 87 & 161 & 93 & 136 \\
\hline Cohabit (F-1) & $\mathbf{5 4 9}$ & 136 & 62 & 55 & 41 & 92 & 69 & 84 \\
\hline
\end{tabular}

30 Korea Immigration Service, Oct. 2014.

31 Ko Pyŏng-kap, Ibid: 30.

32 Korea Immigration Service, Oct. 2014. 


\begin{tabular}{|c|c|c|c|c|c|c|c|c|}
\hline $\begin{array}{l}\text { Permanent } \\
\text { Resident (F-5) }\end{array}$ & 230 & 80 & 27 & 24 & 29 & 21 & 15 & 34 \\
\hline $\begin{array}{l}\text { Work and Visit } \\
\text { (H-2) }\end{array}$ & 229 & 98 & 15 & 23 & 11 & 17 & 40 & 25 \\
\hline Residence (F-2) & 81 & 26 & 10 & 10 & 8 & 4 & 1 & 24 \\
\hline Language (E-2) & 77 & 22 & 7 & 12 & 10 & 13 & 4 & 9 \\
\hline $\operatorname{Art}(E-6)$ & 25 & 16 & & & & & & 9 \\
\hline Study (D-2) & 23 & 8 & & 15 & & & & \\
\hline Religion (D-6) & 6 & & & & 5 & & 1 & \\
\hline $\begin{array}{l}\text { Special Activity } \\
\text { (E-7) }\end{array}$ & 12 & 1 & 3 & 3 & & 2 & 4 & \\
\hline $\begin{array}{l}\text { General Train- } \\
\text { ee (D-4) }\end{array}$ & 5 & 1 & 1 & & & 3 & & \\
\hline $\begin{array}{l}\text { Dependant (F- } \\
\text { 3) }\end{array}$ & 4 & 4 & & & & & & \\
\hline $\begin{array}{l}\text { Technology } \\
\text { Trainee (G-3) } \\
\end{array}$ & 3 & & & & & & & 3 \\
\hline $\begin{array}{l}\text { International } \\
\text { Trade (D-9) } \\
\end{array}$ & 1 & & & & 1 & & & \\
\hline $\begin{array}{l}\text { Working Holi- } \\
\text { day (H-1) }\end{array}$ & 1 & & 1 & & & & & \\
\hline Others (H-1) & 5 & 1 & 1 & 1 & & 2 & & \\
\hline Sum & 3,334 & 879 & 369 & 348 & 219 & 532 & 492 & 495 \\
\hline
\end{tabular}

\section{The Current State of Support for Multicultural Families} and Multicultural Identities

The Present Condition of the Mt. Chirisan Region Multicultural Family Support Institution

The Mt. Chirisan Region Multicultural Family Support Institution run with government funding can be described as the institution representing local multicultural issues. It is in operation in 7 city/kuns in the Mt. Chi- 
risan Region with the exception of Kurye. Each local institution varies in its founding date, scale, and activities. Hamyang-kun founded its institution in 2008, while the others were mostly established around 2011 and 2012. For Kurye, the Kurye-kun Multicultural Family Committee was established instead to handle related work. Of the 7 citiy/kuns, Hamyangkun and Sanch'ŏng-kun run various multicultural family support and education programs. Notably, Hamyang-kun was awarded for having the best visiting education programs for multicultural families in the country, and it also runs a separate professional counseling team. Namwŏn-si and Changsu-kun systematically support foreigners' assimilation to Korea by running social integration programs.

Table 8. The Current States of Multicultural Family Support Institutions in the Mt. Chirisan Region

\begin{tabular}{|c|c|c|c|}
\hline Areas & $\begin{array}{l}\text { Name of the } \\
\text { Institution }\end{array}$ & $\begin{array}{c}\text { Founding } \\
\text { Dates }\end{array}$ & History \\
\hline $\begin{array}{c}\text { Namwŏn- } \\
\text { si }\end{array}$ & $\begin{array}{l}\text { Namwŏn Mul- } \\
\text { ticultural } \\
\text { Family Sup- } \\
\text { port Institution }\end{array}$ & 2012 & $\begin{array}{l}\text { 2009 Nominated for "Child-Raising" } \\
\text { Institute } \\
20101^{\text {st }} \text { Namwŏn Multicultural Festival/ } \\
\text { Vietnam Education Service Activity } \\
\text { 2011 Nominated for Social Integration } \\
\text { Program Institute } \\
\text { 2012 Multicultural Family Support Insti- } \\
\text { tution Consignment Confirmed } \\
2013 \text { Multicultural School Project started }\end{array}$ \\
\hline $\begin{array}{c}\text { Changsu- } \\
\text { kun }\end{array}$ & $\begin{array}{l}\text { Changsu Mul- } \\
\text { ticultural } \\
\text { Family Sup- } \\
\text { port Institution }\end{array}$ & 2011 & $\begin{array}{l}2011 \text { Head of the Institute Appointed } \\
\text { 2012 Support for Multicultural Choir } \\
\text { "Hope" } \\
2013 \text { "Save The Children," "Two Lan- } \\
\text { guages, Twice the Fun" started } \\
\text { 2014 Opened Social Integration Program }\end{array}$ \\
\hline $\begin{array}{c}\text { Koksŏng- } \\
\text { kun }\end{array}$ & $\begin{array}{l}\text { Koksŏng Mul- } \\
\text { ticultural } \\
\text { Family Sup- } \\
\text { port Institution }\end{array}$ & 2012 & $\begin{array}{l}2011 \text { Multicultural Family Adaptation } \\
\text { Support Project } \\
2012 \text { Head of the Institute Appointed }\end{array}$ \\
\hline
\end{tabular}




\begin{tabular}{|c|c|c|c|}
\hline $\begin{array}{l}\text { Kurye- } \\
\text { kun }\end{array}$ & $\begin{array}{l}\text { Kurye Multi- } \\
\text { cultural Family } \\
\text { Committee }\end{array}$ & 2011 & $\begin{array}{l}2011 \text { Kurye Multicultural Family Com- } \\
\text { mittee Founding Convention } \\
\text { 2014 Kurye-kun Multicultural Family } \\
\text { One-for-All, All-for-One event } \\
\text { *Kurye-kun is included in Kwangyang } \\
\text { Multicultural Family Support Institute } \\
\text { area. }\end{array}$ \\
\hline $\begin{array}{l}\text { Hadong- } \\
\text { kun }\end{array}$ & $\begin{array}{l}\text { Hadong Multi- } \\
\text { cultural Family } \\
\text { Support Insti- } \\
\text { tution }\end{array}$ & 2011 & $\begin{array}{l}2011 \text { Opening } \\
2012 \text { Translation/Interpretation started }\end{array}$ \\
\hline $\begin{array}{l}\text { Sanchŏng- } \\
\text { kun }\end{array}$ & $\begin{array}{l}\text { Sanchŏng Mul- } \\
\text { ticultural } \\
\text { Family Sup- } \\
\text { port Institution }\end{array}$ & 2011 & $\begin{array}{l}2011 \text { Opening } \\
2013 \text { School for multicultural- } \\
\text { background women }\end{array}$ \\
\hline $\begin{array}{l}\text { Hamyang- } \\
\text { kun }\end{array}$ & $\begin{array}{l}\text { Hamyang Mul- } \\
\text { ticultural } \\
\text { Family Sup- } \\
\text { port Institution }\end{array}$ & 2008 & $\begin{array}{l}2008 \text { Opening } \\
2009 \text { Awarded the country-wide best in } \\
\text { its visiting education programs for multi- } \\
\text { cultural family } \\
2010 \text { Intern Project for Female Marriage } \\
\text { Migrant } \\
\text { 2011 Nominated for "Child-Raising" } \\
2012 \text { Initiated a separate professional } \\
\text { counseling team }\end{array}$ \\
\hline
\end{tabular}

The Current State of Multicultural Family Support Center Programs

The current states for Mt. Chirisan Regional Multicultural Family Support Centers are based on data obtained from regional homepages for Multicultural Family Support Centers. ${ }^{33}$ As Kurye-kun does not have an official site, an online café for the Kurye-kun Multicultural Family Committee was referenced. ${ }^{34}$ Based on these, Table 9 below was created. Programs being run by Multicultural Family Support Centers in 7city/kuns were regrouped into mainly four areas: education, social integration, finance and employment support, and support for multicultural activities.

33 http://www.liveinkorea.kr/center (April 29 2015).

$34 \mathrm{http}: / /$ cafe.daum.net/grmcc (April 22 2015). 
There are four main characteristics for programs currently running. First, the various multicultural family support programs run by the 7 city/kuns are overall very similar. There are some areas where new programs are being developed, but these are few, and with the difference being that they are limited to the number of programs being run. Also, it is hard to say that there is much difference between the Mt. Chirisan Multicultural Family Support Center's programs and the other metropolitan area's programs. Therefore, the support programs appropriate for inland mountain-range regions-especially for Mt. Chirisan- need to be developed.

Second, social integration programs that help initial settlement and learning of basic Korean makes up the majority of the support program. In terms of social integration programs, there is Multicultural Family Integration Education, Multicultural Counseling, Multicultural Language Development Support Service, Korean Society Assimilation Education (Korean Basic Cooking Class), Local Society Joint Business, Multicultural education, Multicultural Human Rights Education. Hadong-kun is running Family-Loving Day, the Campaign for Family Love, Family exchange of labor, a Family Camping Site for Family Get-togethers, the Family Service Team, the Common Baby-Raising Sharing Program and such as Family Culture services. Also, Rainbow Family's Happy Childbirth, Multicultural Family Joint Weddings, and the Visitors' Consultation Office are examples of specialization movements that are connected to local society. Hadong-kun's case is a special one as other institutions do not run as many education and integration programs.

Third, financial support or employment-related programs that provide consistent help to foreigners settling in Korea after their initial move are limited to perfunctory support. These programs remain at basic levels and provide for training for jobs such as computer education, nail art, quilting, and registration to Worknet, connecting to other job information. There are no plans for mid-to-long term job preparation support. The only case would be the efforts in Changsu-kun to introduce Filipina immigrants as native language teachers. Also, it is difficult for immigrants to collect the funds for initiating large-scale economic activities, as the support is lim- 
ited to small-scale financial support, such as support for multicultural families' internet fees, extracurricular academic fees, and joint marriage and such. It is necessary to provide mid-to-long term systematic employment support for the stable settlement of immigrants, and realistic financial support programs are needed to establish independent economic activities.

Fourth, supporting programs for preserving immigrant cultural diversity and identity are scarce, as most supporting programs for immigrants are focused on one-sided unity by assimilation. The Bilingual Family Environment Creation, Language Learning Class, Marriage Immigrants Interpretation/Translation Service, Multicultural Family Self-Help Meeting, Improvement on Multicultural Awareness, and Local Advertisement movement, Supporting Service for Visiting One's Home Country are passive assistance for the preservation of diverse multicultural identities. It is necessary for Korea to make more effort into the society and system to keep pace with trends in global diversification, and at the same time protect the cultural identities of immigrants. In this process, benchmarking overseas examples such as the United States, China, Russia, Europe and other countries that have already dealt with problems related to multicultural identity would be helpful. Especially, comparative research with the European Alps region, the United States' Appalachian mountain regions, and other inland mountain-range regions and the cultural identities of immigrants would be needed.

Table 9. Current Running Program by 7 Multicultural Family Support Center in Mt. Chirisan Region

\begin{tabular}{c|l|l|l|l}
\hline Areas & Education & $\begin{array}{c}\text { Social Inte- } \\
\text { gration }\end{array}$ & $\begin{array}{c}\text { Finan- } \\
\text { cial/Employment } \\
\text { Support }\end{array}$ & $\begin{array}{l}\text { Multicultural Activ- } \\
\text { ity Support }\end{array}$ \\
\hline $\begin{array}{c}\text { Nam- } \\
\text { wŏn-si }\end{array}$ & $\begin{array}{l}\text { Korean } \\
\text { Education, } \\
\text { Visiting } \\
\text { Education }\end{array}$ & $\begin{array}{l}\text { Social Integra- } \\
\text { tion Program, } \\
\text { Multicultural } \\
\text { Family Inte- } \\
\text { gration Educa- }\end{array}$ & $\begin{array}{l}\text { Eonnection to Mul- } \\
\text { Employ- } \\
\text { ment/Education } \\
\text { Support, Child- }\end{array}$ & $\begin{array}{l}\text { Language Learning } \\
\text { Class, Marriage Mi- } \\
\text { grant Interpreta- } \\
\text { tion/Translation Ser- } \\
\text { vice, Self-Helping }\end{array}$ \\
\hline
\end{tabular}




\begin{tabular}{|c|c|c|c|c|}
\hline & & $\begin{array}{l}\text { tion, Multicul- } \\
\text { tural Service } \\
\text { Team, Person- } \\
\text { al/Family } \\
\text { Consulting, } \\
\text { Language } \\
\text { Development } \\
\text { Support Pro- } \\
\text { ject }\end{array}$ & $\begin{array}{l}\text { raising Information } \\
\text { Sharing Place }\end{array}$ & Meeting \\
\hline $\begin{array}{l}\text { Chang- } \\
\text { su-kun }\end{array}$ & $\begin{array}{l}\text { Korean } \\
\text { Education, } \\
\text { Visiting } \\
\text { Education }\end{array}$ & $\begin{array}{l}\text { Social Integra- } \\
\text { tion Program, } \\
\text { Multicultural } \\
\text { Family Inte- } \\
\text { gration Educa- } \\
\text { tion, Multicul- } \\
\text { tural Service } \\
\text { Team, Job } \\
\text { Education, } \\
\text { Multi- } \\
\text { Language } \\
\text { Development } \\
\text { Support Pro- } \\
\text { ject, Extra- } \\
\text { curricular } \\
\text { Academy } \\
\text { Financial } \\
\text { Support for } \\
\text { Multicultural } \\
\text { Children, } \\
\text { Visiting Mul- } \\
\text { ticultural } \\
\text { School }\end{array}$ & $\begin{array}{l}\text { Employment } \\
\text { Help/Education } \\
\text { Support, Local So- } \\
\text { ciety Funding Pro- } \\
\text { ject (Employment } \\
\text { of Philippines fe- } \\
\text { male migrants) }\end{array}$ & $\begin{array}{l}\text { Marriage Migrant } \\
\text { Interpreta- } \\
\text { tion/Translation Ser- } \\
\text { vice, Education about } \\
\text { Understanding Multi- } \\
\text { culture, Improvement } \\
\text { on Awareness of } \\
\text { Multiculture Pro- } \\
\text { ject/Publicizing, Bi- } \\
\text { lingual Family Envi- } \\
\text { ronment Making } \\
\text { Program, Support } \\
\text { for Visiting Home } \\
\text { Country, Multicul- } \\
\text { tural Self-Helping } \\
\text { Meeting }\end{array}$ \\
\hline $\begin{array}{l}\text { Koksŏng } \\
\text {-kun }\end{array}$ & $\begin{array}{l}\text { Korean } \\
\text { Education, } \\
\text { Visiting } \\
\text { Education }\end{array}$ & $\begin{array}{l}\text { Family Inte- } \\
\text { gration Pro- } \\
\text { gram, Korean } \\
\text { Society Adap- } \\
\text { tation Pro- } \\
\text { gram (Korean } \\
\text { Cooking } \\
\text { Class), Con- } \\
\text { sultation, } \\
\text { Language } \\
\text { Development }\end{array}$ & $\begin{array}{l}\text { Employment Educa- } \\
\text { tion (Computer, Nail } \\
\text { Art, Quilt), Adapta- } \\
\text { tion Support Project } \\
\text { (Japanese/English), } \\
\text { Local Society Coop- } \\
\text { eration Network } \\
\text { Project }\end{array}$ & $\begin{array}{l}\text { Multiculture Educa- } \\
\text { tion, Language } \\
\text { Learning Class, In- } \\
\text { terpreta- } \\
\text { tion/Translation Sup- } \\
\text { port Program, Self- } \\
\text { Helping Meeting } \\
\text { (Vietnam, Philip- } \\
\text { pines), Multicultural } \\
\text { Family Service } \\
\text { Team }\end{array}$ \\
\hline
\end{tabular}




\begin{tabular}{|c|c|c|c|c|}
\hline & & $\begin{array}{l}\text { Support Pro- } \\
\text { ject }\end{array}$ & & \\
\hline $\begin{array}{c}\text { Kurye- } \\
\text { kun }\end{array}$ & $\begin{array}{l}\text { Multicul- } \\
\text { tural Fami- } \\
\text { ly Visiting } \\
\text { Education }\end{array}$ & $\begin{array}{l}\text { Multicultural } \\
\text { Family Cook- } \\
\text { ing, Multicul- } \\
\text { tural Family } \\
\text { Festival, Mul- } \\
\text { ticultural- } \\
\text { family Wom- } \\
\text { en Education }\end{array}$ & $\begin{array}{l}\text { Multicultural Joint } \\
\text { Marriage Support, } \\
\text { Internet Fee Sup- } \\
\text { port for Multicul- } \\
\text { tural Families }\end{array}$ & $\begin{array}{l}\text { Support on Visiting } \\
\text { Home Country for } \\
\text { Multicultural Family, } \\
\text { Multicultural Self- } \\
\text { Helping Meeting }\end{array}$ \\
\hline $\begin{array}{l}\text { Hadong- } \\
\text { kun }\end{array}$ & $\begin{array}{l}\text { Korean } \\
\text { Education, } \\
\text { Visiting } \\
\text { Education }\end{array}$ & $\begin{array}{l}\text { Education at } \\
\text { Each Stages } \\
\text { of Life, Fami- } \\
\text { ly-Fraternity } \\
\text { Program, Vis- } \\
\text { iting Father } \\
\text { Education, } \\
\text { Multicultural } \\
\text { Family Educa- } \\
\text { tion, Multicul- } \\
\text { tural Gender } \\
\text { Equality Ed- } \\
\text { ucation, Mul- } \\
\text { ticultural Con- } \\
\text { sultation, Lo- } \\
\text { cal Society } \\
\text { Joint Project } \\
\text { (Specializa- } \\
\text { tion), Lan- } \\
\text { guage Devel- } \\
\text { opment Pro- } \\
\text { gram, Multi- } \\
\text { cultural Hu- } \\
\text { man Rights } \\
\text { Education }\end{array}$ & $\begin{array}{l}\text { Multicultural Family } \\
\text { Education on Basic } \\
\text { Employment }\end{array}$ & $\begin{array}{l}\text { Improving Awareness } \\
\text { of Multicultural Fam- } \\
\text { ily, Multicultural } \\
\text { Family Self-Helping } \\
\text { Meeting, Interpreta- } \\
\text { tion/Translation Ser- } \\
\text { vice, Building Bilin- } \\
\text { gual Family Envi- } \\
\text { ronment }\end{array}$ \\
\hline $\begin{array}{c}\text { Sanchŏn } \\
\text { g-kun }\end{array}$ & $\begin{array}{l}\text { Korean } \\
\text { Education, } \\
\text { Visiting } \\
\text { Education }\end{array}$ & $\begin{array}{l}\text { Multicultural } \\
\text { Family Inte- } \\
\text { gration Educa- } \\
\text { tion, Individu- } \\
\text { al Family } \\
\text { Consultation, } \\
\text { Multicultural } \\
\text { Family Lan- }\end{array}$ & $\begin{array}{l}\text { Multicultural Family } \\
\text { Employ- } \\
\text { ment/Education } \\
\text { Support (Registering } \\
\text { to Worknet), Basic } \\
\text { Education on Em- } \\
\text { ployment }\end{array}$ & $\begin{array}{l}\text { Multicultural Shar- } \\
\text { ing Service Team, } \\
\text { Multicultural Self- } \\
\text { Helping Meeting, } \\
\text { Improving Awareness } \\
\text { of Multicultural Fam- } \\
\text { ily/Publicizing Local } \\
\text { Society, Intepreta- }\end{array}$ \\
\hline
\end{tabular}




\begin{tabular}{|c|c|c|c|c|}
\hline & & $\begin{array}{l}\text { guage Devel- } \\
\text { opment Sup- } \\
\text { port Project }\end{array}$ & & $\begin{array}{l}\text { tion/Translation Sup- } \\
\text { port Program }\end{array}$ \\
\hline $\begin{array}{c}\text { Ha- } \\
\text { myang- } \\
\text { kun }\end{array}$ & $\begin{array}{l}\text { Korean } \\
\text { Education, } \\
\text { Visiting } \\
\text { Education }\end{array}$ & $\begin{array}{l}\text { Fammily Edu- } \\
\text { cation, Multi- } \\
\text { cultural Chil- } \\
\text { dren Program, } \\
\text { Gender Equal- } \\
\text { ity Program, } \\
\text { Education } \\
\text { Understanding } \\
\text { and Aware- } \\
\text { ness of Multi- } \\
\text { culture, Hu- } \\
\text { man } \\
\text { Rights/Law } \\
\text { Education, } \\
\text { Korea Adapta- } \\
\text { tion Program, } \\
\text { Language } \\
\text { Development } \\
\text { Service, Per- } \\
\text { sonal/Group } \\
\text { Consultation }\end{array}$ & $\begin{array}{l}\text { Basic Job Educa- } \\
\text { tion Sharing Ser- } \\
\text { vice Team, ITQ } \\
\text { Preparation Class, } \\
\text { Registering to } \\
\text { Worknet, Providing } \\
\text { Employment Infor- } \\
\text { mation }\end{array}$ & $\begin{array}{l}\text { Intepreta- } \\
\text { tion/Translation Sup- } \\
\text { port Program, Publi- } \\
\text { cizing Local Society, } \\
\text { Running Local Socie- } \\
\text { ty Network Site, } \\
\text { Improving Awareness } \\
\text { of Multiculture, Mul- } \\
\text { ticultural Family Self- } \\
\text { Helping Meeting }\end{array}$ \\
\hline
\end{tabular}

Limits to Multicultural Family Support Programs and Multicultural Identity.

We have examined the current state of their supporting programs, their problems, and some proposed solutions of the Multicultural Family Support Centers of $7 \mathrm{Mt}$. Chirisan Regions. For now, the main issue is related to support programs for education immigrants require in their initial settlement and social integration, and the insufficient support for joint employment education, financial support, multicultural activity support and so on. Currently, our society and government needs to actively develop a higher level of social integration and employment education support programs, and carry out policies that will preserve the diverse cultural identities of immigrants.

Concurrently, differentiated multicultural family support programs ap- 
propriate for Mt. Chirisan, an inland mountain region, need to be developed. For this, the Multicultural Family Support Center of the 7 city/kuns, 3 provincial governments and the Education Office adjacent to Mt. Chirisan, Sunchon National University, and Kŏngsang University and other university institutions and civic social groups must work together. Chŏnnam Education Office may be able to turn a new leaf by starting an "Inland Mountain Region Rainbow Project," similar to its "Marine Rainbow Project." Also, the 3 provinces bordering Mt. Chirisan have a relatively higher percentage of immigrants in their population. To improve relations with immigrants, the 3 provinces should develop teaching materials about East Asian multicultural identity for discussion among school students. There is a need for a joint effort by provincial organizations and local universities to make a "Multicultural Family Archive" to store various data related to multicultural identity that multicultural families possess. As a beta, linking the Mt. Chirisan Region Multicultural Family Archive with the Institute of Mt. Chirisan Region Culture may be an appropriate starting point. Furthermore, preserving and developing the identity of the Mt. Chirisan Region's multicultural families would be a great help in mutual cooperation between East Asian countries. Local-oriented international cultural exchange programs with countries that have a significant presence in the Mt. Chirisan Region-namely, Vietnam, China, and Japanwould be ideal. The Institute of Mt. Chirisan Regional Culture, which held its $4^{\text {th }}$ International Conference on East Asian Mountain Culture, can play a role in such East Asian cultural exchange.

\section{Conclusion}

This paper aimed to talk about defining the area designated the "Mt. Chirisan Region," the current state and historical/geographical background of its immigrants, their characteristics, and integration issues. This article defined the range of Mt. Chirisan Region as 7 city/kuns: Namwŏnsi, Changsu, Koksŏng, Kurye, Hadong, Sanchŏng, and Hamyang. Rather 
than use natural ecological standards and geospatial standards which are too restrictive, this article's definition was based on socio-economic and administrative standards which are more helpful in understanding the Mt. Chirisan Region's immigrant issues.

The historical/geographical characteristics of Mt. Chirisan are as follows: the visible mountain configuration of Mt. Chirisan is a trunk-branch connection type and the spatial pattern of the stream network on Mt. Jiri shows a radial shape, with a winding watercourse; streams of Mt. Chirisan are rich with water. Soil conditions are fertile and wild animals are abundant. The rice farming on Mt. Chirisan Area has been affected by these geographical conditions. The land ownership ratio of privately owned land and Buddhist temples are relatively higher than other mountains like Mt. Halla. The numbers of settlement are numerous, the distribution region is broad. Consequently, rice farming scale and numbers of population have increased over time.

As the Mt. Chirisan Region mainly consists of mountainous and agricultural areas, the immigrant induction effect in socio-economically was low relative to urban and industrial areas. This can be identified from the ratio of foreigners in Mt. Chirisan to 3 provinces (Chŏnbuk, Chŏnnam, and Kyŏngnam), which is lower than the ratio of Korean citizens in the Mt. Chirisan Region. It was also noted that, as the percentage of immigrants through marriage in Mt. Chirisan was high relative to urban or industrial areas, the female foreigner ratio was higher than that of male. In regard to the home countries of these immigrants, women from SouthEast Asia and North-East Asia account for the majority. In relation to employment-related residents, non-employment immigration and visiting employment make up $40 \%$, which means most immigrants come to Korea due to international marriage.

In this article, I have examined the 7 local Multicultural Family Support Centers in the Mt. Chirisan Region, their current support programs, their problems, and possible solutions. Currently, education necessary for initial immigrant settlement and social integration support programs account for the largest part of support, while there is a lack of support in 
regard to employment-related education, financial support, and multicultural activity support. In the future, our society and government need to actively develop a higher level of social integration and employment education support programs, and carry out policies that will protect the diverse cultural identities of immigrants. Simultaneously, differentiated multicultural family support programs appropriate for Mt. Chirisan, an inland mountain region, need to be developed.

\section{References}

1. Korean Center for Multicultural Family Support, http://www.liveink orea.kr/center 2015 (Oct. 14. 2015).

2. Korea Immigration Service, Tonggyeweolbo (Monthly Statistics) (Oct. 2014).

3. Korea National Park Service, Gukripgonweon Gibontongyeo (Basic Statistics of National Park) (2013).

4. Korea National Park Service, Mt. Chirisangukripgongweon Saengmulgweon Bojeonjieok ( Biosphere Reserve of Mt. Chirisan National Park (2013).

5. Korean Statistical Information Service, http://kosis.kr.

6. Kurye-kun Center for Multicultural Family Support (April 22. 2015), http://cafe.daum.net/grmcc.

7. Mt. Chirisan Tourism Development Association, http://www.Chirisa ntour.go.kr. (Oct. 14. 2015).

8. An, Mi-jŏng, "Haehangdosi ŭi Yijuja: Pusansi Haenyŏ Community Chŏngaeyangsang (Migrant of Seaport City: Features of Women Diver's Community in Busan, Korea," Yǒksawagyŏngye (History and Border), 89 (Dec. 2013).

9. Choe, Wŏnsŏk, "Mt. Chirisan kwa Mt. Hallasan ŭi Yŏksajiri jŏk Paegyŏng kwa Hyŏnhwang Pigyo Koch'al (Comparative Research on the Histo-geographical Background of Mt. Chirisan and Mt. Hallasan)," Namdo Munhwa Yŏnku (The Journal of Namdo Cultural 
Studies), 26, (June 2014).

10. Choe, Wŏnsŏk, "Korean Mountain Studies: Tradition and Knowledge," Journal of Mountains and Humanities, vol. 1 (September 2015): 95 97

11. Chŏng, Ch'i-yŏng, Mt. Chirisan ui Nongyeop gwa Chonrakyeongu (Study on Agriculture and Village in Mt. Chirisan) (Seoul: Research Institute of Korean Studies at Korea University 2006).

12. Chŏng, Chang-yŏb, "Hanguk Tamunhwa Kajokjŏngch'aek ŭi Sŏnggyŏkyŏnku: Tonghwajuŭi Chŏngch'aek ttonŭn Tamunhwajuch'ŏngch'ak (A Study on the Characterristics of Multicultural Family Policy in Korea: Asimilation Policy or Multiculturalism policy)," (Doctoral Dissertation, Sunchon National University 2013).

13. Chŏng, Chang-yŏb \& Chŏng, Sun-kwan, "Hanguk Tamunhwagjŏk Jŏngch'aekŭi Chŏnghangsŏng Punsŏk: Tonghwachŭiwa Tamunhwachuŭi (Characteristics of Multicultural Family Policy in Korea: Assimilation or Multiculturalism)," Chibangjŏngbuyŏnku (The Korean Journal of Local Government Studies), vol. 17, no. 4 (Winter 2014).

14. Ko, Byŏng-kap, Tamunhwasahoe ŭi Damunhwajeonchaek ae taehan Sŏnhaengyŏnku (Studies on Multicutural Policy based on Multiculturalism)," Chibangjach 'iyŏnku (Studies on Loca lself- government), 19 (2012).

15. Kim, Jŏng-nam \& Li, Yŏnghwan, "Tamunhwa Kyoyuk ŭi Chuyomunje: Pulpyŏngdŭng kwa Sahoejŏngŭi (The Main Problems of Multicultural Education: Inequality and Social Justice), Kyoyukyŏnku (Studis on Education), no. 34 (2011).

16. Li, Sŭng-hi, "Chŏnamjiyŭk ŭi Tamunhwa Hyŏngsang: Chiyŏkchukjewa Tamunhwa Kajok ŭi Sangkwangwangŏyrŭl Chunsimŭro (Multicultural Phenomena in South Jolla Province: an Analysis of Interactions between Local Festival and Multicultural Families)," Ch'asedae Inmunsahoeyŏnku (Study on Future Humanties and Social Science), vol. 8 (Dec. 2011). 
17. T'ak, Hanmyŏng; Kim, Sŏnghan; Son, Il, "Chihyŏngkhakjŏk Sanji ŭi Punp'o wa Konggan Chŏk T' ŭksŏng ae taehan Yŏnku (Study on Geographical Distribution and Spatial Characteristics," Taehanjirihakhoeji (Journal of Korean Geographical Society), vol.48, no.1 (2013). 


\section{The Current State and Historico-geographical Background of Mt. Chirisan Region Immigrants}

Kang Sungho

This paper examined the historico-geographical background and current state of immigrants in the area designated as the "Mt. Chirisan Region," their characteristics, and related integration issues. This article defines the Mt. Chirisan Region as the 7 cities/kuns of Namwŏn-si, Changsu-kun, Koksŏng-kun, Kurye-kun, Hadong-kun, Sanchŏng-kun, and Hamyang-kun. As the Mt. Chirisan Region mainly consists of mountainous and agricultural areas, the immigrant induction effect socio-economically was low relative to urban and industrial areas. It was also noted that, as the percentage of marriage immigration in Mt. Chirisan was high relative to urban or industrial areas, the female foreigner ratio was higher than that of male foreigners. In regard to the home countries of immigrants, women from South-East Asia and North-East Asia accounted for the majority. Also, this article examines the current situation of support programs of 7 local Multicultural Family Support Centers in the Mt. Chirisan Region, their problems, and probably solutions. Based on the historical development of the region and recent social changes, our society and government need to actively develop a higher level of social integration and employment education support programs, and carry out policies that will protect the diverse cultural identities of immigrants. In addition, differentiated multicultural family support programs appropriate for Mt. Chirisan, an inland mountain region, need to be developed.

Keywords: Mt. Chirisan, East Asia, Immigrant, Multi-cultural identity, inland mountain region 


\title{
$<$ 국문초록>
}

\section{지리산 지역 이주자의 역사지리학적인 배경과 현황}

\author{
강성호 (순천국립대학교 사학과 교수)
}

이 글은 “지리산 지역”이라고 지정된 곳으로 이주한 사람들의 역사적/지리학적 배경과 현황, 그들의 특성, 관련된 종합적인 주제들을 분석하였다. 이 논문에서는 남원시, 장수군, 곡성군, 구례군, 하동군, 산청군, 함양군 등의 7 개 시/군 지역을 지리산 지역으로 정의한다. 지리산 지역은 대부분 산간 지역과 농촌 지역으로 구 성되어 있기 때문에, 이주자들의 사회경제적인 유인 효과는 상대적으로 도시 지역 이나 산업 지역과는 관계가 적다. 또한 지리산 지역에서의 결혼 이주 비율이 도시 나 산업적인 지역에 비해 상대적으로 높기 때문에, 외국인 여성의 비율이 외국인 남성의 비율보다 높다는 점도 확인할 수 있다. 이주자들의 고향을 살펴보면, 동남 아시아와 동북아시아 출신 여성이 대부분을 차지한다는 것을 알 수 있다. 그리고 이 연구는 지리산 지역에 있는 7개의 다문화 가족 지원 센터의 지원 프로그램 현 황과 문제, 가능한 해결책에 대해서도 분석하고 있다. 지역의 역사적인 발전과 최 근의 사회적 변화를 바탕으로 우리 사회와 정부는 더 높은 수준의 사회적 이주와 직업훈련 지원 프로그램을 개발할 필요가 있으며 이주자들의 다양한 문화적 정체 성을 보호할 수 있는 정책들을 실행해야 한다. 또한 내륙 산간 지역인 지리산 지 역에 좀 더 적합한 차별화된 다문화 가정 지원 프로그램이 개발될 필요가 있다.

주제어: 지리산, 동아시아, 이주자, 다문화 정체성, 내륙 산간 지역 